\title{
$450{ }^{\circ} \mathrm{C}$ Isothermal Section of the AI-V-Zn System
}

\author{
Fucheng Yin, Sha Zheng, Xinming Wang, Zhi li, and Manxiu Zhao
}

(Submitted January 10, 2012; in revised form March 19, 2012)

\begin{abstract}
The $450{ }^{\circ} \mathrm{C}$ isothermal section of $\mathrm{Al}-\mathrm{V}-\mathrm{Zn}$ ternary system has been determined experimentally by means of optical microscopy, scanning electron microscopy coupled with energy-dispersive spectrometric, and x-ray diffraction. A new ternary compound named $T$, containing 8.2-9.9 at.\% $\mathrm{V}, 12.1-27.4$ at.\% $\mathrm{Zn}$, is positively identified for the first time in this study. The $\mathrm{T}$ phase only equilibrates with $\mathrm{Al}_{3} \mathrm{~V}, \alpha$-Al, and $\mathrm{L}-\mathrm{Zn}$. Experimental results indicates that the maximal solubility of $\mathrm{Al}$ in $\mathrm{VZn}_{3}$ is 25.2 at.\%. The maximum solubility of $\mathrm{Zn}$ in $\alpha-\mathrm{V}$ is 5.7 at.\%. The $\mathrm{Zn}$ solubility in $\mathrm{Al}-\mathrm{V}$ compounds $\left(\mathrm{Al}_{8} \mathrm{~V}_{5}, \mathrm{Al}_{3} \mathrm{~V}, \mathrm{Al}_{23} \mathrm{~V}_{4}, \mathrm{Al}_{45} \mathrm{~V}_{7}\right.$, and $\left.\mathrm{Al}_{21} \mathrm{~V}_{2}\right)$ is 10.6, 9.2, 1.2, 0.6, and 0.4 at. $\%$, respectively. The maximum solubility of $\mathrm{Al}$ in $\mathrm{V}$ is 41.0 at.\%. Nine three-phase regions have been confirmed experimentally in this ternary system.
\end{abstract}

Keywords Al-V-Zn system, phase diagram, T phase

\section{Introduction}

Hot-dip galvanizing is widely used to protect steel components exposed to corrosive environment. However, galvanizing Si-containing steels remains a technical challenge as it produces dull and excessively thick coatings with poor adhesion. This phenomenon is referred to as the Sandlin effect or $\mathrm{Si}$ reactivity by the galvanizers. ${ }^{[1-3]} \mathrm{A}$ practical solution is to galvanize the steels in alloyed baths. Aluminum is one of the most important elements in galvanizing. Virtually all galvanizing baths contain aluminum. ${ }^{[4]}$ In continuous galvanizing, $0.1-0.3 \mathrm{wt} . \%$ aluminum is added into the zinc bath to suppress $\mathrm{Fe}-\mathrm{Zn}$ compound formation and to maintain a thin, ductile coating. In that process, a very thin inhibition layer of $\mathrm{Fe}_{2} \mathrm{Al}_{5}$ forms at the steel-coating interface and acts as a barrier between the steel and molten zinc, preventing iron-zinc compounds formation. ${ }^{[4-8]}$ Lower $(<0.005$ wt.\%) level of aluminum is used in general galvanizing, the main reason for adding aluminum to the general galvanizing bath is to brighten the coating surface and reduce oxidation of the molten zinc. ${ }^{[4]}$ To satisfy the demands for better corrosion-resistance and oxidation-resistance at elevated temperatures, higher level of aluminum is added into zinc bath. Recently $\mathrm{Su}$ et al. ${ }^{[9]}$ have found that $\mathrm{V}$ is an effective bath additive that offers adequate control of $\mathrm{Si}$ reactivity in galvanizing. It's important to have some knowledge of the phase diagram on the Al-Fe-V-Zn system in order to understand the

Fucheng Yin, Sha Zheng, Xinming Wang, Zhi li, and Manxiu Zhao, Key Laboratory of Materials Design and Preparation Technology of Hunan Province, School of Mechanical Engineering, Xiangtan University, Xiangtan 411105, Hunan, People's Republic of China. Contact e-mail: fuchengyin@xtu.edu.cn. behavior of the added elements during galvanizing. The development of this quaternary system requires the information of the four ternary systems in the zinc-rich corner. The Al-Fe-Zn system has been thoroughly assessed by different authors. ${ }^{[10,11]}$ The Fe-V-Zn system has been experimentally investigated recently. ${ }^{[12]}$ The iron-rich of Al-Fe-V system has been studied. ${ }^{[13]}$ However, the information of phase equilibrium in the Al-V-Zn ternary system has not been reported yet. The purpose of the present study is to experimentally determine the $\mathrm{Al}-\mathrm{V}-\mathrm{Zn}$ isothermal section at $450{ }^{\circ} \mathrm{C}$.

\section{Literature Data}

The Al-Zn binary systems has been investigated repeatedly and given in Massalski's Handbook of Binary Phase diagram. ${ }^{[14]}$ For the Al-Zn system there are only three condensed phases, i.e., liquid, Al-based FCC and Zn-based HCP. It was thermodynamically evaluated by Chen and Chang $^{[15]}$ and Mey. ${ }^{[16]}$

In the Al-V binary system five compounds have been found to exist, i.e., $\mathrm{Al}_{21} \mathrm{~V}_{2}, \mathrm{Al}_{45} \mathrm{~V}_{7}, \mathrm{Al}_{23} \mathrm{~V}_{4}, \mathrm{Al}_{3} \mathrm{~V}$, and $\mathrm{Al}_{8} \mathrm{~V}_{5}$. The phase equilibrium in the Al-rich part of the Al-V system are quite complex. Richter and Ipser ${ }^{[17]}$ have reinvestigated the system and found all five compounds to melt peritectically. Only two of the phases, $\mathrm{Al}_{3} \mathrm{~V}$ and $\mathrm{Al}_{8} \mathrm{~V}_{5}$, showed a small homogeneity range. Gong et al. ${ }^{[18]}$ have performed a thermodynamic reassessment of the system including the new results of Ref 17 to their optimization.

The earliest phase diagram of the $\mathrm{V}-\mathrm{Zn}$ system was reported by Chasanov et al. ${ }^{[19]}$ Two compounds, $\mathrm{V}_{4} \mathrm{Zn}_{5}$ and $\mathrm{VZn}_{3}$ were found in the system. Piotrowski ${ }^{[20]}$ proposed another compound VZn16 which underwent peritectic melting at a temperature only slightly above the eutectic temperature. Smith ${ }^{[21]}$ critically assessed the system based on these experimental results. Recently $\mathrm{Wu}$ et al. ${ }^{[2]}$ have found that $\mathrm{VZn}_{16}$, with $\mathrm{V}$ content of about 5.8 at.\%, was indeed an equilibrium phase and its peritectic temperature is about $427{ }^{\circ} \mathrm{C}$. In addition, the solubility of $\mathrm{Zn}$ in $\alpha-\mathrm{V}$ is 2.1 at. $\%$ and the solubility of $\mathrm{V}$ in $\mathrm{Zn}$ is 0.3 at. $\%$ at $450{ }^{\circ} \mathrm{C}$. 
In the present work, the binary system Al-Zn, Al-V, and $\mathrm{V}-\mathrm{Zn}$ from Ref 14, 18, and 22, respectively, are accepted. And the crystallographic parameters for the binary compounds which are involved in the present work are listed in the Table 1.

\section{Experimental Methods}

A total of 25 alloys were prepared to determine the equilibrium phases in the Al-V-Zn system. The design compositions of these alloys are detailed in Table 2 . The purity of raw materials, i.e., $\mathrm{Al}$ and $\mathrm{V}$ powders, and $\mathrm{Zn}$ chips, is 99.99 wt.\%. The mixture of the raw materials, with the weight of each constituent precisely measured and with a total weight of $3 \mathrm{~g}$, was put into a corundum crucible and then sealed in an evacuated quartz tube. Each sample was heated to $1150{ }^{\circ} \mathrm{C}$ and kept for two days, then quenched in water. During the preparation of samples, in order to minimize $\mathrm{Zn}$ loss and obtain a relatively compact sample, a bottom-quenching technique ${ }^{[23]}$ was used. The quenched samples were then resealed and annealed at $450{ }^{\circ} \mathrm{C}$ for 60 days to ensure the establishment of an equilibrium state. The treatment was completed with rapid water quenching to preserve the equilibrium state at $450{ }^{\circ} \mathrm{C}$.

Sections of the specimens were prepared in the conventional way for metallographic examinations. A nital etching solution was used for revealing the microstructure details and a conventional optical microscope was used for the preliminary examination of all specimens. Detailed metallographic examinations and compositional analyses of various phases in the samples were performed using a JSM-6360LV scanning electron microscope coupled with energy-dispersive spectrometric (SEM-EDS) under backscattered electron image (BES) mode. The constituent phases of the alloys were further determined by analyzing $\mathrm{x}$-ray diffraction patterns generated by a D/max-rA x-ray diffractometer, operating at $40 \mathrm{kV}$ and $100 \mathrm{~mA}$ with $\mathrm{Cu} \mathrm{Ka}$ radiation. The compositions reported in this study are the averages of at least five measurements.

\section{Results and Discussion}

All phases found in the alloys are listed in Table 2 (Column 3) together with the chemical compositions determined by the SEM-EDS technique (Column 4, 5, and 6). The $\eta-Z n$ phase is marked as "L-Zn" in the present work because it is in the liquid state at $450{ }^{\circ} \mathrm{C}$.

An important discovery of this study is the new ternary compound named $\mathrm{T}$, containing $8.2-9.9$ at.\% $\mathrm{V}$, $12.1-27.4$ at. $\% \mathrm{Zn}$. Based on the SEM-EDS analyses, the $\mathrm{T}$ phase is confirmed to be in equilibrium with $\mathrm{Al}_{3} \mathrm{~V}$, $\mathrm{L}-\mathrm{Zn}$, and $\alpha-\mathrm{Al}$. Figure 1(a) and (b) shows the microstructure and x-ray diffraction pattern of alloy A6. Results show that alloy A6 (Zn61-Al35-V4) corresponds to T, $\mathrm{Al}_{3} \mathrm{~V}$, and $\mathrm{L}-\mathrm{Zn}$ three-phase equilibrium. The difference in the relief of the three phases is remarkable. The light gray $\mathrm{T}$ phase and black $\mathrm{Al}_{3} \mathrm{~V}$ phase coexist with the matrix of the L-Zn phase which contains 24.4 at. $\%$ of $\mathrm{Al}$. In this alloy the maximum solubility of $\mathrm{Zn}$ in the $\mathrm{T}$ phase is 27.3 at. $\%$.

Figure 2(a) is the microstructure of alloy A7 (Zn48Al48-V4), SEM-EDS analyses indicates that the black block $\mathrm{T}$ which contains 23.1 at. $\% \mathrm{Zn}$ and 8.2 at. $\% \mathrm{~V}$, and the gray phase $\alpha$-Al coexist with the matrix of the L-Zn phase. Obviously the $\mathrm{T}$ phase shows a better corrosion resistance to nital etching solution than $\alpha$-Al phase. Figure 2(b) shows the $\mathrm{x}$-ray diffraction pattern of alloy A7 which confirms the three-phase equilibrium state.

The microstructure of alloy A16 (Zn8-Al80-V12) is shown in Fig. 3(a). The phases existing in this alloy are identified as $\mathrm{Al}_{3} \mathrm{~V}, \boldsymbol{\alpha}-\mathrm{Al}$, and $\mathrm{T}$. In this alloy the $\mathrm{T}$ phase contains the minimum content of $\mathrm{Zn}$ about 12.1 at.\%. Obviously, the result obtained by XRD of this alloy confirms three-phase equilibrium state, as shown in Fig. 3(b).

Figure 4(a) is the microstructure of alloy A1 (Zn55$\mathrm{Al} 30-\mathrm{V} 15)$ which consists of three phases, i.e., the black $\mathrm{Al}_{3} \mathrm{~V}$ phase, the light gray $\mathrm{VZn}_{3}$ phase and the matrix of the $\mathrm{L}-\mathrm{Zn}$ phase. It is worth noting that the Al solubility in $\mathrm{VZn}_{3}$ reaches 25.2 at.\%, so the formula of $\mathrm{VZn}_{3}$ changes to $\mathrm{VZn}_{2} \mathrm{Al}$. But it is not a new ternary compound; it is the $\mathrm{Al}$ atoms occupying the position of $\mathrm{Zn}$ atoms without changing the crystal structure of $\mathrm{VZn}_{3}$ and forming a solid solution. As a result, the $\mathrm{X}$-ray diffraction pattern of the $\mathrm{VZn}_{3}$ in this alloy has an offset compared to the standard $\mathrm{VZn}_{3} \mathrm{x}$-ray diffraction pattern. Figure 4(b) shows the x-ray diffraction pattern of alloy A1 which confirms a three-phase equilibrium state.

Alloy A12 (Zn3-A192-V5) corresponds to the $(\alpha-\mathrm{Al}+$ $\mathrm{Al}_{21} \mathrm{~V}_{2}+\mathrm{Al}_{45} \mathrm{~V}_{7}$ ) three-phase equilibrium state as shown in

Table 1 Crystallographic parameters for the binary compounds required in the present work

\begin{tabular}{|c|c|c|c|c|c|c|}
\hline \multirow[b]{2}{*}{ Compound } & \multirow[b]{2}{*}{ Crystal system } & \multirow[b]{2}{*}{ Space group } & \multicolumn{3}{|c|}{ Lattice parameters, nm } & \multirow[b]{2}{*}{ References } \\
\hline & & & $a$ & $b$ & $c$ & \\
\hline $\mathrm{Al}_{8} \mathrm{~V}_{5}$ & $\mathrm{DO}_{8}$ & $I \overline{4} 3 m$ & 0.92345 & $\cdots$ & $\cdots$ & {$[17,24]$} \\
\hline $\mathrm{Al}_{3} \mathrm{~V}$ & $\mathrm{DO}_{22}$ & $14 / \mathrm{mmm}$ & 0.3780 & $\cdots$ & $\cdots$ & {$[17,24]$} \\
\hline $\mathrm{Al}_{23} \mathrm{~V}_{4}$ & Hexagonal & $P 6_{3} / m m c$ & 0.76928 & $\cdots$ & 1.7040 & {$[17,24]$} \\
\hline $\mathrm{Al}_{45} \mathrm{~V}_{7}$ & Monoclinic & $C 2 / m$ & 2.54 & $0.759, \beta=127^{\circ}$ & 1.10 & {$[17,24]$} \\
\hline $\mathrm{Al}_{21} \mathrm{~V}_{2}$ & F.C.C & $F d \overline{3} m$ & 1.4492 & $\ldots$ & ... & {$[17,24]$} \\
\hline $\mathrm{V}_{4} \mathrm{Zn}_{5}$ & Tetragonal & $I 4 / \mathrm{mmm}$ & 0.8910 & $\cdots$ & 0.3227 & {$[21]$} \\
\hline $\mathrm{VZn}_{3}$ & B.C.C & $P m \overline{3} m$ & 0.3848 & $\cdots$ & & [21] \\
\hline
\end{tabular}


Table 2 Alloys and phase compositions (at.\%)

\begin{tabular}{|c|c|c|c|c|c|}
\hline Alloy & Designed composition & Phase & $\mathbf{Z n}$ & Al & $\mathbf{V}$ \\
\hline \multirow[t]{3}{*}{ A1 } & Zn55-Al30-V15 & L-Zn & 97.8 & 1.7 & 0.5 \\
\hline & & $\mathrm{Al}_{3} \mathrm{~V}$ & 8.1 & 65.3 & 26.6 \\
\hline & & $\mathrm{VZn}_{3}$ & 49.4 & 25.2 & 25.4 \\
\hline \multirow[t]{2}{*}{$\mathrm{A} 2$} & Zn82-A13-V15 & $\mathrm{L}-\mathrm{Zn}$ & 98.6 & 0.6 & 0.8 \\
\hline & & $\mathrm{VZn}_{3}$ & 70.2 & 4.9 & 24.9 \\
\hline \multirow[t]{2}{*}{ A3 } & Zn90-A14-V6 & $\mathrm{L}-\mathrm{Zn}$ & 98.3 & 1.0 & 0.7 \\
\hline & & $\mathrm{VZn}_{3}$ & 61.2 & 14.1 & 24.7 \\
\hline \multirow[t]{2}{*}{ A4 } & Zn70-A115-V15 & $\mathrm{L}-\mathrm{Zn}$ & 98.4 & 1.2 & 0.4 \\
\hline & & $\mathrm{VZn}_{3}$ & 52.8 & 22.3 & 24.9 \\
\hline \multirow[t]{2}{*}{ A5 } & $\mathrm{Zn} 86-\mathrm{A} 12-\mathrm{V} 2$ & $\mathrm{~L}-\mathrm{Zn}$ & 88.5 & 11.5 & $\sim 0$ \\
\hline & & $\mathrm{Al}_{3} \mathrm{~V}$ & 7.7 & 66.1 & 26.2 \\
\hline \multirow[t]{3}{*}{ A6 } & Zn61-Al35-V4 & $\mathrm{T}$ & 27.3 & 64.3 & 8.4 \\
\hline & & $\mathrm{Al}_{3} \mathrm{~V}$ & 6.2 & 68.2 & 25.6 \\
\hline & & $\mathrm{L}-\mathrm{Zn}$ & 75.6 & 24.4 & $\sim 0$ \\
\hline \multirow[t]{3}{*}{ A7 } & Zn48-Al48-V4 & L-Zn & 75.4 & 24.6 & $\sim 0$ \\
\hline & & $\alpha-\mathrm{Al}$ & 38.5 & 61.5 & $\sim 0$ \\
\hline & & $\mathrm{T}$ & 23.1 & 68.7 & 8.2 \\
\hline \multirow[t]{2}{*}{ A8 } & Zn33-Al64-V3 & $\mathrm{T}$ & 18.3 & 73.4 & 8.3 \\
\hline & & $\alpha-\mathrm{Al}$ & 37.8 & 62.1 & 0.1 \\
\hline \multirow[t]{2}{*}{ A9 } & Zn14-A183-V3 & $\alpha-\mathrm{Al}$ & 13.7 & 86.0 & 0.3 \\
\hline & & $\mathrm{T}$ & 13.3 & 77.7 & 9.0 \\
\hline \multirow[t]{2}{*}{ A10 } & Zn23-Al74-V3 & $\mathrm{T}$ & 15.5 & 76.0 & 8.5 \\
\hline & & $\alpha-\mathrm{Al}$ & 26.1 & 73.7 & 0.2 \\
\hline \multirow[t]{2}{*}{ A11 } & Zn10-Al73-V17 & $\mathrm{Al}_{3} \mathrm{~V}$ & 2.6 & 72.8 & 24.6 \\
\hline & & $\mathrm{T}$ & 17.6 & 73.2 & 9.2 \\
\hline \multirow[t]{3}{*}{ A12 } & Zn3-A192-V5 & $\alpha-\mathrm{Al}$ & 4.1 & 95.6 & 0.3 \\
\hline & & $\mathrm{Al}_{21} \mathrm{~V}_{2}$ & 0.4 & 90.4 & 9.2 \\
\hline & & $\mathrm{Al}_{45} \mathrm{~V}_{7}$ & 0.6 & 86.7 & 12.7 \\
\hline \multirow[t]{3}{*}{ A13 } & Zn3-A182-V15 & $\mathrm{Al}_{3} \mathrm{~V}$ & 1.8 & 73.7 & 24.5 \\
\hline & & $\alpha-\mathrm{Al}$ & 7.9 & 91.8 & 0.3 \\
\hline & & $\mathrm{Al}_{23} \mathrm{~V}_{4}$ & 1.2 & 83.2 & 15.6 \\
\hline \multirow[t]{2}{*}{ A14 } & Zn15-A170-V15 & $\mathrm{Al}_{3} \mathrm{~V}$ & 3.8 & 71.4 & 24.8 \\
\hline & & $\mathrm{T}$ & 20.0 & 70.1 & 9.9 \\
\hline \multirow[t]{2}{*}{ A15 } & Zn3-A164-V33 & $\mathrm{Al}_{3} \mathrm{~V}$ & 2.6 & 70.8 & 26.6 \\
\hline & & $\mathrm{Al}_{8} \mathrm{~V}_{5}$ & 2.9 & 59.0 & 38.1 \\
\hline \multirow[t]{3}{*}{ A16 } & Zn8-A180-V12 & $\mathrm{Al}_{3} \mathrm{~V}$ & 2.3 & 73.2 & 24.5 \\
\hline & & $\alpha-\mathrm{Al}$ & 10.9 & 88.8 & 0.3 \\
\hline & & $\mathrm{T}$ & 12.1 & 78.6 & 9.3 \\
\hline \multirow[t]{2}{*}{ A17 } & Zn65-Al5-V30 & $\mathrm{VZn}_{3}$ & 68.9 & 5.1 & 26.0 \\
\hline & & $\alpha-V$ & 4.2 & 12.7 & 83.1 \\
\hline \multirow[t]{2}{*}{ A18 } & Zn55-Al15-V30 & $\mathrm{VZn}_{3}$ & 60.4 & 13.7 & 25.9 \\
\hline & & $\alpha-V$ & 3.9 & 24.6 & 71.5 \\
\hline A19 & Zn50-A120-V30 & $\mathrm{VZn}_{3}$ & 52.7 & 21.5 & 25.8 \\
\hline & & $\alpha-V$ & 4.4 & 34.7 & 60.9 \\
\hline A 20 & Zn11-A145-V44 & $\mathrm{Al}_{8} \mathrm{~V}_{5}$ & 10.6 & 49.5 & 39.9 \\
\hline & & $\alpha-V$ & 5.7 & 41.0 & 53.3 \\
\hline & & $\mathrm{VZn}_{3}$ & 50.7 & 23.5 & 25.8 \\
\hline A 21 & Zn30-A140-V30 & $\mathrm{VZn}_{3}$ & 50.2 & 24.1 & 25.7 \\
\hline & & $\mathrm{Al}_{3} \mathrm{~V}$ & 9.2 & 63.5 & 27.3 \\
\hline & & $\mathrm{Al}_{8} \mathrm{~V}_{5}$ & 5.0 & 57.2 & 37.8 \\
\hline A22 & Zn35-A140-V25 & $\mathrm{VZn}_{3}$ & 49.7 & 24.7 & 25.6 \\
\hline & & $\mathrm{Al}_{3} \mathrm{~V}$ & 9.1 & 65.3 & 25.6 \\
\hline A 23 & $\mathrm{Zn} 42-\mathrm{Al} 3-\mathrm{V} 55$ & $\mathrm{VZn}_{3}$ & 70.7 & 3.0 & 26.3 \\
\hline & & $\mathrm{V}_{4} \mathrm{Zn}_{5}$ & 54.7 & 0.5 & 44.8 \\
\hline & & $\alpha-V$ & 4.8 & 4.3 & 90.9 \\
\hline
\end{tabular}


Section I: Basic and Applied Research

Table 2 Continued

\begin{tabular}{|c|c|c|c|c|c|}
\hline Alloy & Designed composition & Phase & Zn & Al & $\mathbf{V}$ \\
\hline \multirow[t]{2}{*}{ A24 } & Zn66-A14-V30 & $\mathrm{VZn}_{3}$ & 70.1 & 3.8 & 26.1 \\
\hline & & $\alpha-\mathrm{V}$ & 4.2 & 8.0 & 87.8 \\
\hline \multirow[t]{2}{*}{ A25 } & Zn3-Al53-V44 & $\alpha-V$ & 2.8 & 39.2 & 58.0 \\
\hline & & $\mathrm{Al}_{8} \mathrm{~V}_{5}$ & 2.7 & 57.8 & 39.5 \\
\hline
\end{tabular}

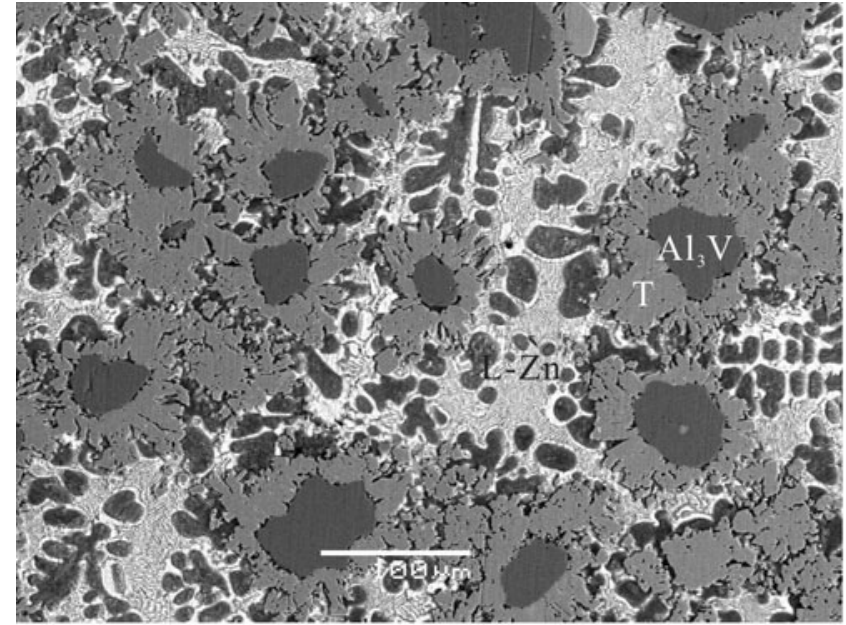

(a)

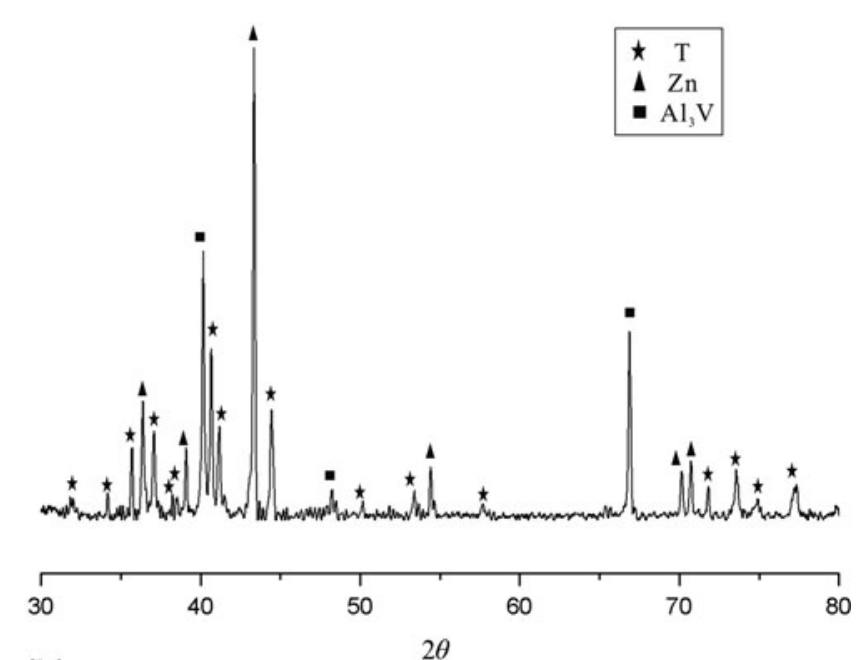

(b)

Fig. 1 BSE image (a) and x-ray diffraction pattern (b) of Alloy A6 (Zn61-Al35-V4). Three phases, $\mathrm{Al}_{3} \mathrm{~V}, \mathrm{~L}-\mathrm{Zn}$, and $\mathrm{T}$ coexist in this alloy

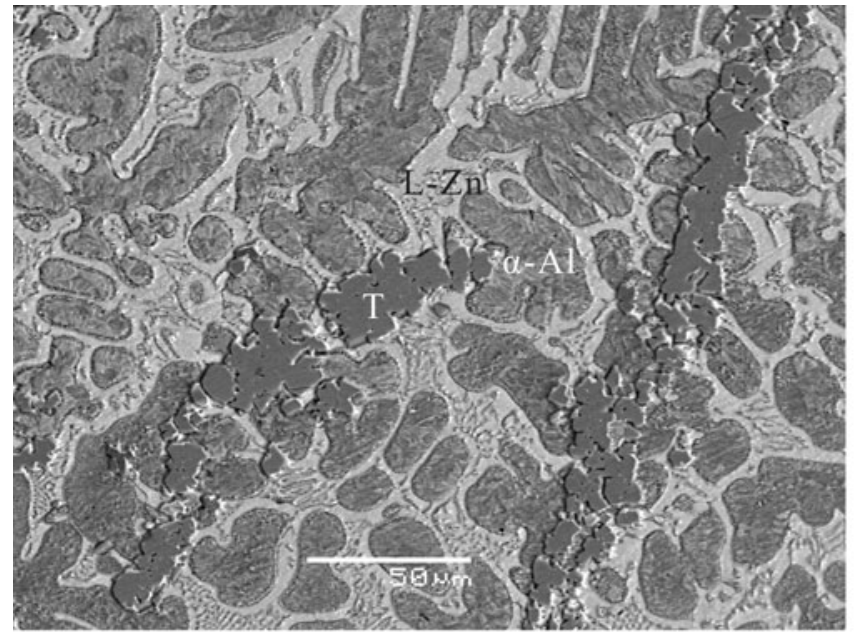

(a)

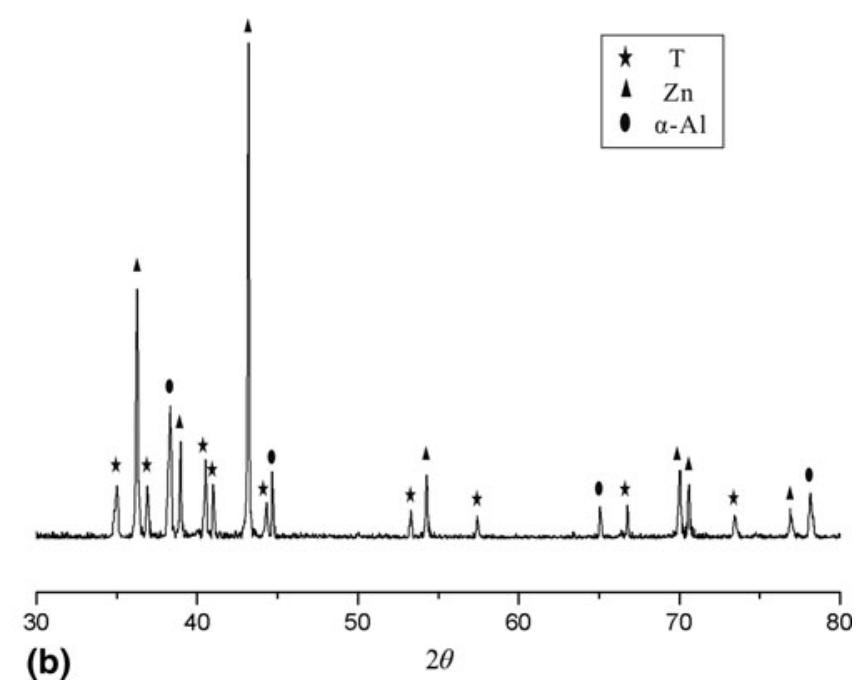

(b)

Fig. 2 The microstructure (a) and x-ray diffraction pattern (b) of Alloy A7 (Zn48-Al48-V4) indicate the equilibrium of T, $\alpha$-Al, and L-Zn 


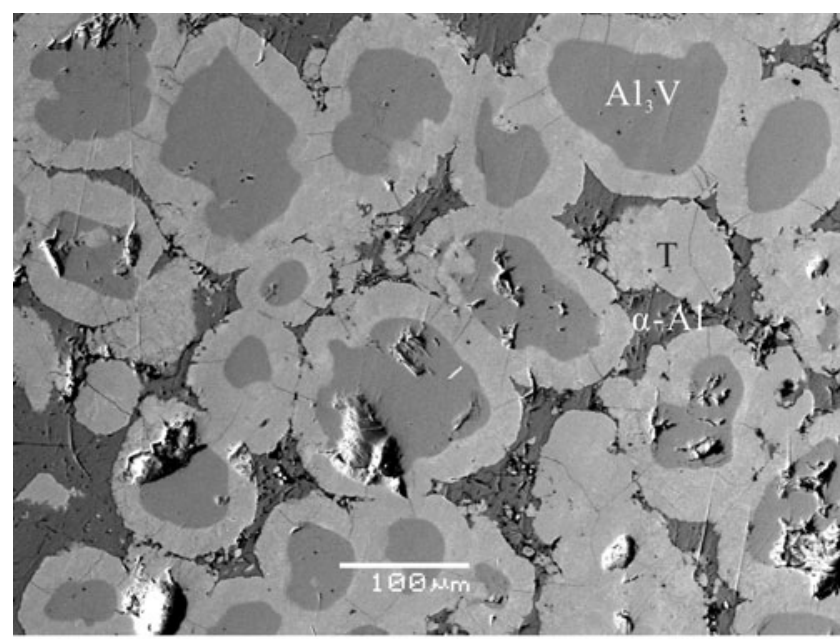

(a)

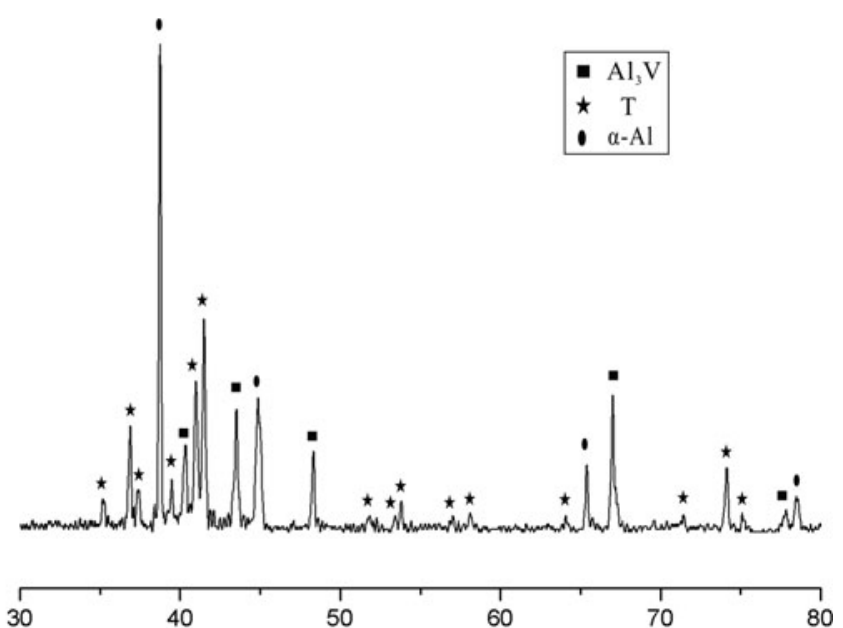

(b)
$2 \theta$

Fig. 3 SEM micrograph (a) and x-ray diffraction pattern (b) of Alloy A16 (Zn8-A180-V12) suggest the equilibrium of $\mathrm{Al}_{3} \mathrm{~V}, \boldsymbol{\alpha}-\mathrm{Al}$, and $\mathrm{T}$

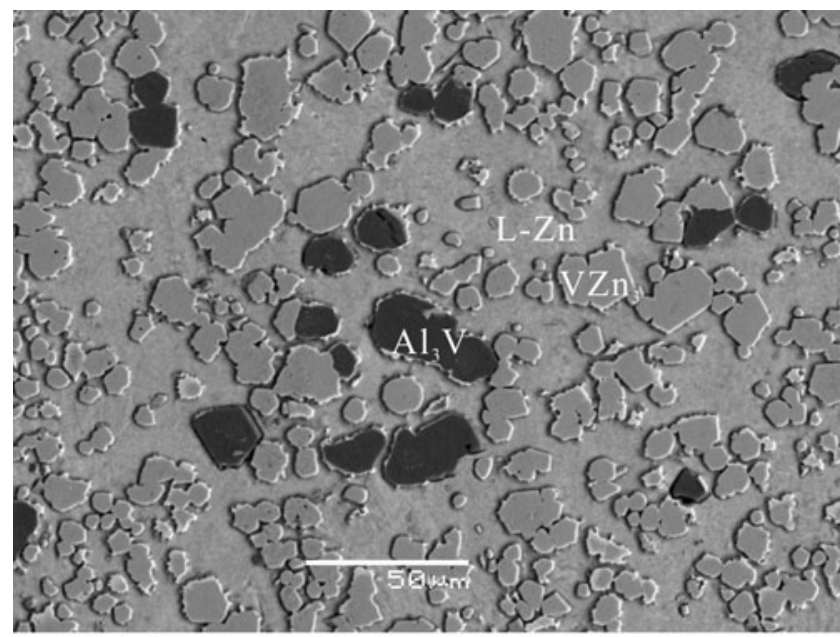

(a)

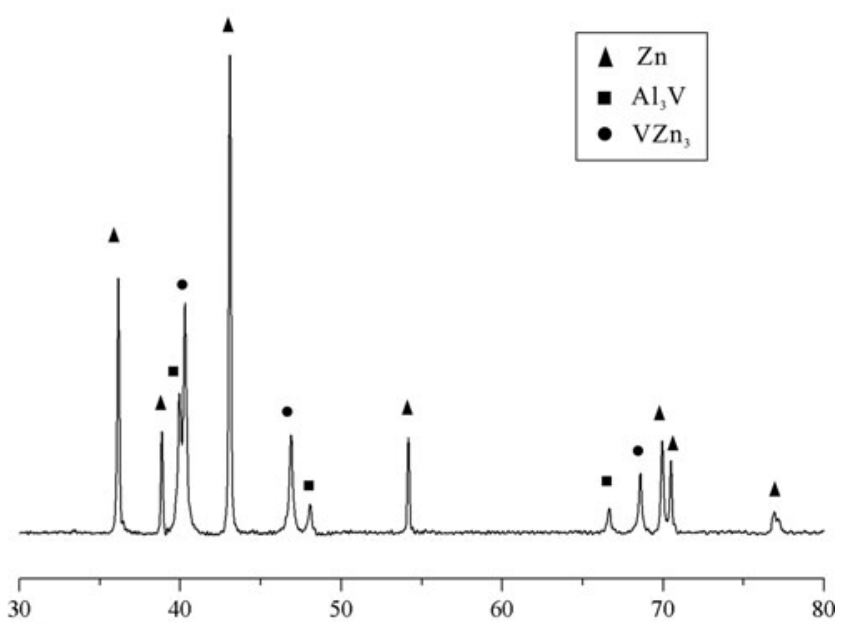

(b)
$2 \theta$

Fig. 4 SEM image (a) and x-ray diffraction pattern (b) of Alloy A1 (Zn55-Al30-V15), showing the existence of L-Zn, $\mathrm{Al}_{3} \mathrm{~V}$, and $\mathrm{VZn} \mathrm{n}_{3}$

Fig. 5(a), which is confirmed by x-ray diffraction pattern as shown in Fig. 5(b). In this alloy the $\mathrm{Zn}$ solubility in $\mathrm{Al}_{21} \mathrm{~V}_{2}$ and $\mathrm{Al}_{45} \mathrm{~V}_{7}$ is 0.4 and 0.6 at.\%, respectively.

Figure 6(a) is the microstructure of alloy A13 (Zn3$\mathrm{A} 182-\mathrm{V} 15)$, indicating that three phases, i.e., $\mathrm{Al}_{3} \mathrm{~V}, \alpha-\mathrm{Al}$, and $\mathrm{Al}_{23} \mathrm{~V}_{4}$ coexist in this alloy. Figure $6(\mathrm{~b})$ is the $\mathrm{x}$-ray diffraction pattern of this alloy. This pattern clearly indicates that this alloy is $\mathrm{Al}_{3} \mathrm{~V}, \alpha-\mathrm{Al}$, and $\mathrm{Al}_{23} \mathrm{~V}_{4}$ three-phase equilibrium state. The solubility of $\mathrm{Zn}$ in $\mathrm{Al}_{3} \mathrm{~V}, \mathrm{Al}_{23} \mathrm{~V}_{4}$, and $\alpha-\mathrm{Al}$ is $1.8,1.2$, and 7.9 at.\%, respectively.

The microstructure of alloy A20 (Zn11-Al45-V44) is shown in Fig. 7. The relief of $\mathrm{Al}_{8} \mathrm{~V}_{5}$ and $\alpha-\mathrm{V}$ don't have many differences. The SEM-EDS analyses suggest that the sunken block is the $\mathrm{Al}_{8} \mathrm{~V}_{5}$ phase and the other gray one is the $\alpha-\mathrm{V}$ phase. In this alloy the solubility of $\mathrm{Zn}$ reaches 5.7 at. $\%$ in $\alpha-\mathrm{V}$. The reason is that the addition of $\mathrm{Al}$ increases the solubility of $\mathrm{Zn}$ in $\alpha-\mathrm{V}$. The white block is $\mathrm{VZn}_{3}$ which takes a small proportion in this alloy. The Al solubility in $\mathrm{VZn}_{3}$ is 23.5 at.\%. The $\mathrm{x}$-ray of alloy A20 only shows the peaks of $\mathrm{Al}_{8} \mathrm{~V}_{5}$ and $\alpha-\mathrm{V}$ because of the little $\mathrm{VZn}_{3}$ content in this alloy. But according to the SEM-EDS analyses and other equilibria, it can be obviously inferred that this alloy corresponds to the $\mathrm{Al}_{8} \mathrm{~V}_{5}, \alpha-\mathrm{V}$, and $\mathrm{VZn}_{3}$ three-phase equilibrium state. 


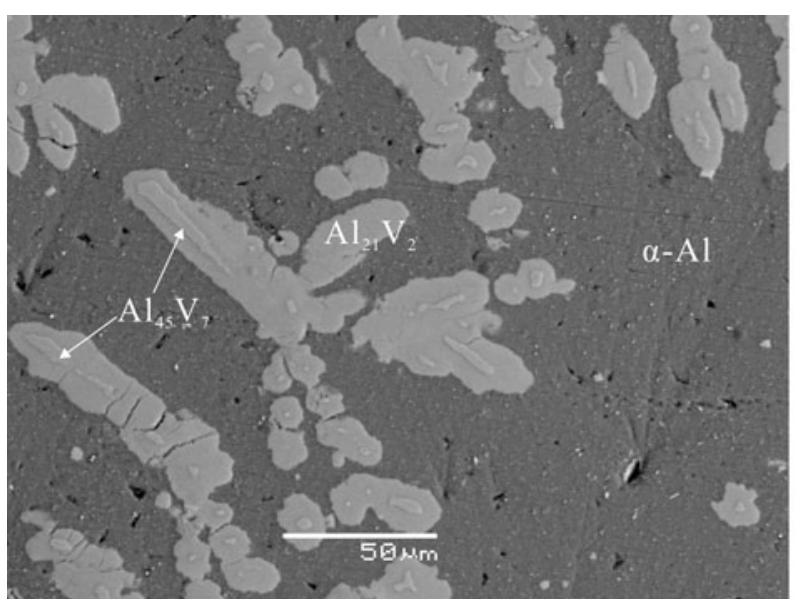

(a)

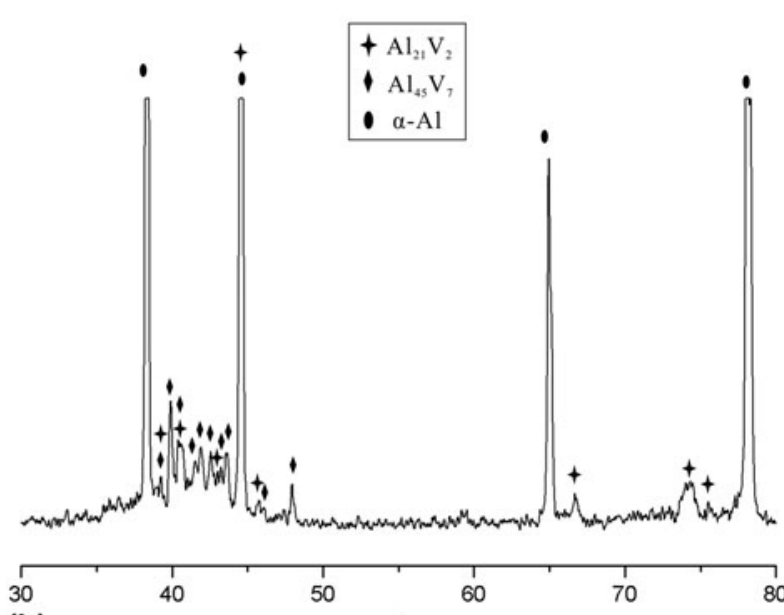

(b)

Fig. 5 The microstructure (a) and x-ray diffraction pattern (b) from Alloy A12 (Zn3-A192-V5) confirm the $\alpha-\mathrm{Al}_{\mathrm{p}}$ phase, $\mathrm{Al}{ }_{21} \mathrm{~V}_{2}$ phase, and $\mathrm{Al}_{45} \mathrm{~V}_{7}$ phase

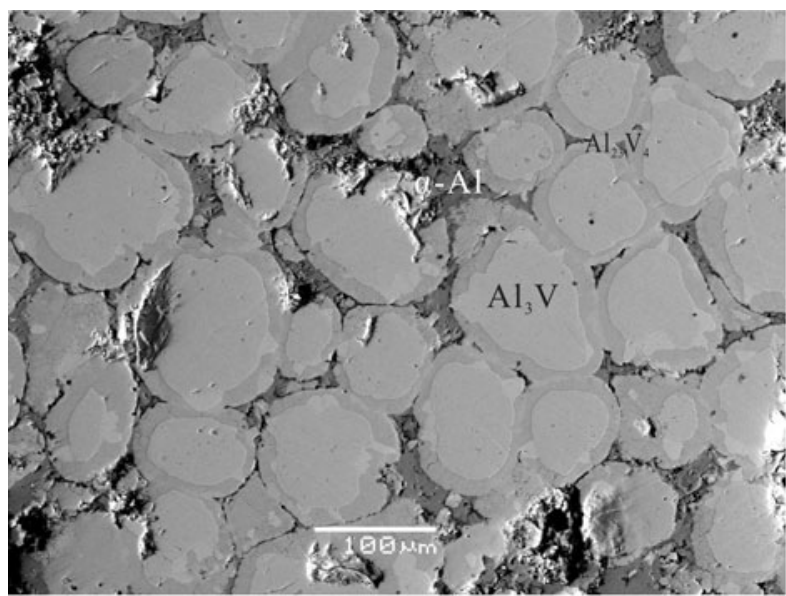

(a)

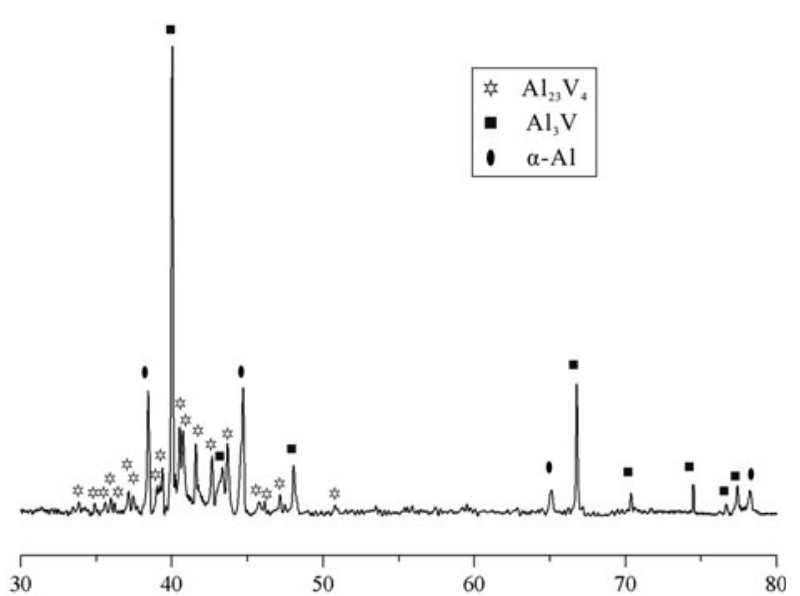

(b)
$2 \theta$

Fig. 6 BSE image (a) and x-ray diffraction pattern (b) of Alloy A13 (Zn3-Al82-V15) consists of $\mathrm{Al}_{3} \mathrm{~V}, \alpha-\mathrm{Al}_{2}$ and $\mathrm{Al}_{23} \mathrm{~V}_{4}$

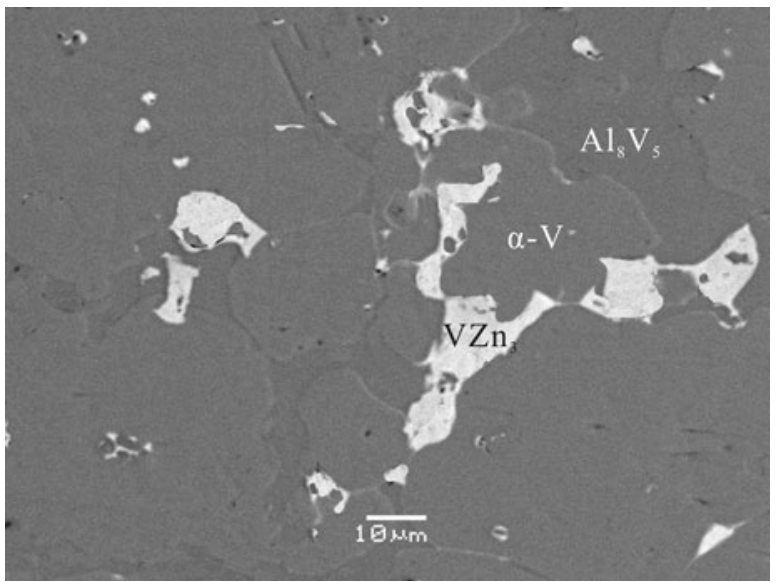

Fig. 7 The differences in chemical composition afford contrasts for three phases, $\mathrm{Al}_{8} \mathrm{~V}_{5}, \alpha-\mathrm{V}$, and $\mathrm{VZn}_{3}$, on a BSE micrograph of Alloy A20 (Zn11-A145-V44)
The microstructure of alloy A21 (Zn30-A140-V30), as shown in Fig. 8(a), indicates that this alloy consists of three phases, i.e., $\mathrm{VZn}_{3}, \mathrm{Al}_{8} \mathrm{~V}_{5}$, and $\mathrm{Al}_{3} \mathrm{~V}$. The relieves of the three phases are remarkable, the white block $\mathrm{VZn}_{3}$ phase, the gray $\mathrm{Al}_{8} \mathrm{~V}_{5}$ phase, and dark gray $\mathrm{Al}_{3} \mathrm{~V}$ phase coexist in this alloy. And the existence of the three phases can be confirmed by the x-ray diffraction pattern in Fig. 8(b). The $\mathrm{Zn}$ solubility in $\mathrm{Al}_{8} \mathrm{~V}_{5}$ and $\mathrm{Al}_{3} \mathrm{~V}$ is 5.0 and 9.2 at.\%, respectively. And the solubility of $\mathrm{Al}$ in $\mathrm{VZn}_{3}$ reaches 24.1 at. $\%$.

On the $\mathrm{V}-\mathrm{Zn}$ rich side, the only three-phase equilibrium region, $\alpha-\mathrm{V}+\mathrm{VZn}_{3}+\mathrm{V}_{4} \mathrm{Zn}_{5}$, is found in the alloys $\mathrm{A} 23$ (Zn42-A13-V55). The BSE morphology of this alloy is shown in Fig. 9(a). The relief of $\mathrm{VZn}_{3}$ and $\mathrm{V}_{4} \mathrm{Zn}_{5}$ is difficult to distinguish. According to the SEM-EDS analyses, the light gray block is $\mathrm{V}_{4} \mathrm{Zn}_{5}$, and the relatively white one is $\mathrm{VZn}_{3}$. However, they could be clearly differentiated from the x-ray pattern as shown in Fig. 9(b). SEM-EDS analyses suggest that $\mathrm{Al}$ has 3.0 and 0.5 at.\% solubility in $\mathrm{VZn}_{3}$ and 


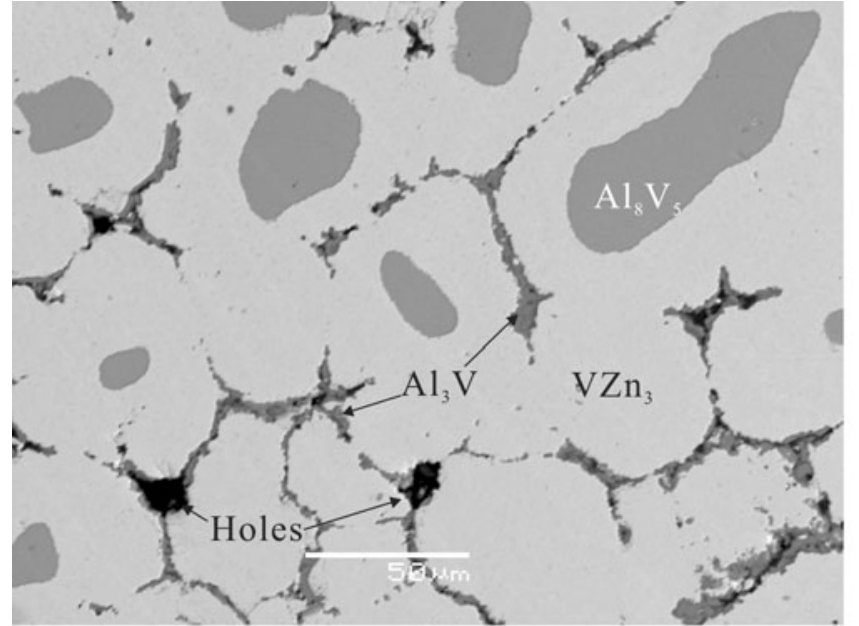

(a)

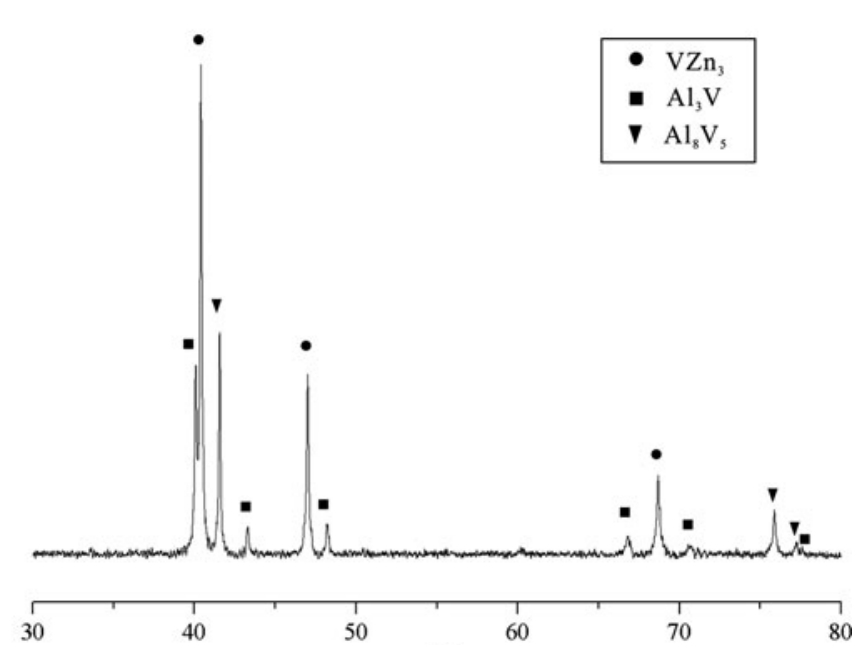

(b)

$2 \theta$

Fig. 8 The microstructure (a) and x-ray diffraction pattern (b) show three phases equilibrium, $\mathrm{VZn}_{3}, \mathrm{Al}_{8} \mathrm{~V}_{5}$, and $\mathrm{Al}_{3} \mathrm{~V}$, of $\mathrm{Allloy}^{\mathrm{A} 21}$ (Zn30-A140-V30)

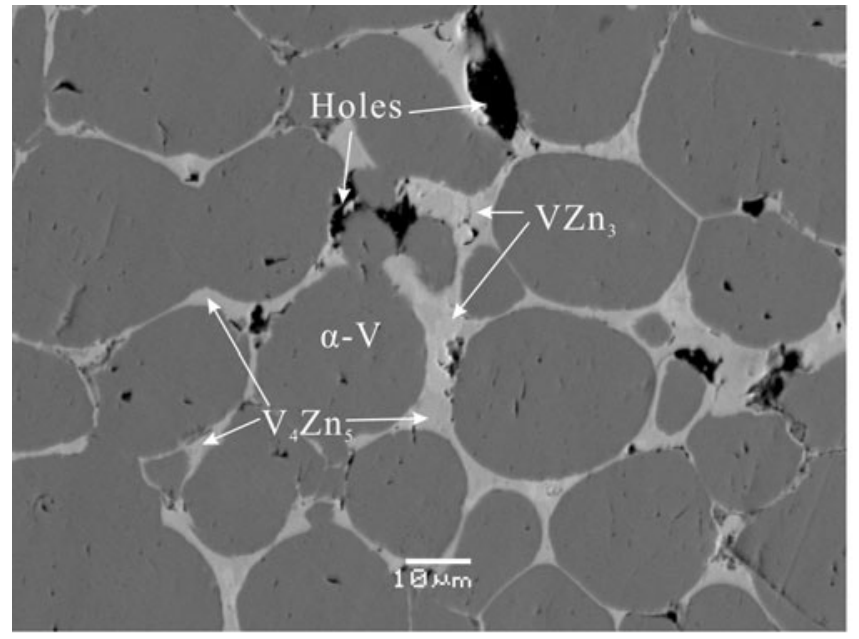

(a)

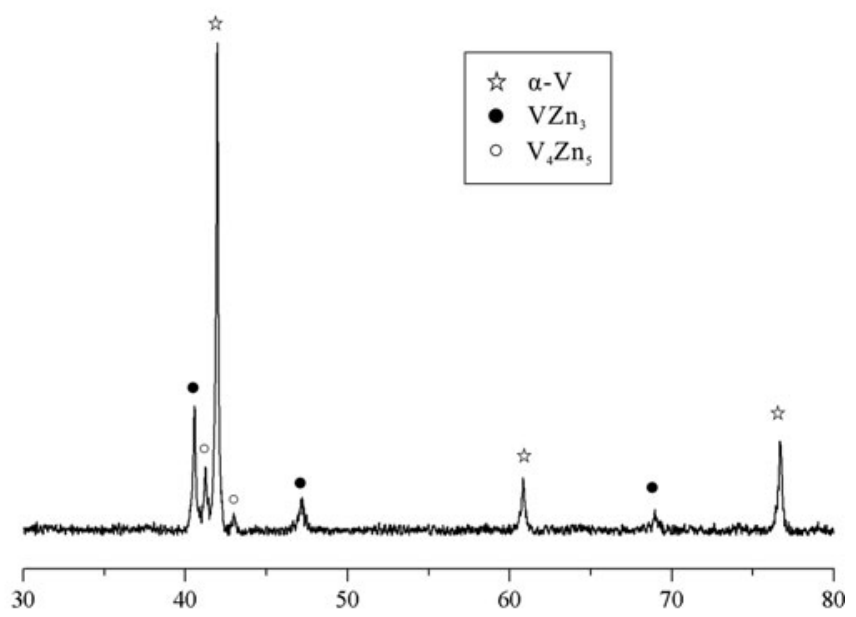

(b)
$2 \theta$

Fig. 9 BSE image (a) and (b) x-ray diffraction pattern of Alloy A23 (Zn42-Al3-V55).Analyses suggest this alloy is in $\alpha$-V, VZn ${ }_{3}$, and $\mathrm{V}_{4} \mathrm{Zn}_{5}$ three-phase equilibrium state at $450{ }^{\circ} \mathrm{C}$

$\mathrm{V}_{4} \mathrm{Zn}_{5}$, respectively. On the other hand, 4.8 at. $\% \mathrm{Zn}$ is detected in $\alpha-V$ phase.

The alloys mentioned above are the alloys in three-phase equilibrium state, the alloys in two-phase equilibrium state are not explained particularly, and their compositional details are listed in Table 2.

Based on the results of microstructures observation and phase analyses, including XRD and SEM-EDS analyses, combined with the information of the binary systems in relevant literature, the $450{ }^{\circ} \mathrm{C}$ isothermal section of $\mathrm{Al}-\mathrm{V}-\mathrm{Zn}$ ternary system is constructed, as shown in Fig. 10. Nine threephase regions have been determined experimentally, i.e., $\mathrm{L}-\mathrm{Zn}+\mathrm{VZn}_{3}+\mathrm{Al}_{3} \mathrm{~V}, \mathrm{~L}-\mathrm{Zn}+\alpha-\mathrm{Al}+\mathrm{T}, \mathrm{L}-\mathrm{Zn}+\mathrm{Al}_{3} \mathrm{~V}+\mathrm{T}$, $\alpha-\mathrm{Al}+\mathrm{T}+\mathrm{Al}_{3} \mathrm{~V}, \quad \mathrm{Al}_{21} \mathrm{~V}_{2}+\mathrm{Al}_{45} \mathrm{~V}_{7}+\alpha-\mathrm{Al}, \quad \alpha-\mathrm{Al}+\mathrm{Al}_{23}$ $\mathrm{V}_{4}+\mathrm{Al}_{3} \mathrm{~V}, \mathrm{Al}_{3} \mathrm{~V}+\mathrm{Al}_{8} \mathrm{~V}_{5}+\mathrm{VZn}_{3}, \mathrm{Al}_{8} \mathrm{~V}_{5}+\mathrm{VZn}_{3}+\alpha-\mathrm{V}$, and $\alpha-\mathrm{V}+\mathrm{VZn}_{3}+\mathrm{V}_{4} \mathrm{Zn}_{5}$. The equilibria of $\mathrm{Al}_{21} \mathrm{~V}_{2}+\mathrm{Al}_{45}$ $\mathrm{V}_{7}+\alpha-\mathrm{Al}$, and $\alpha-\mathrm{Al}+\mathrm{Al}_{23} \mathrm{~V}_{4}+\mathrm{Al}_{3} \mathrm{~V}$ suggest that there is a three-phase field of the $\mathrm{Al}_{45} \mathrm{~V}_{7}, \mathrm{Al}_{23} \mathrm{~V}_{4}$, and $\alpha$-Al phase. 


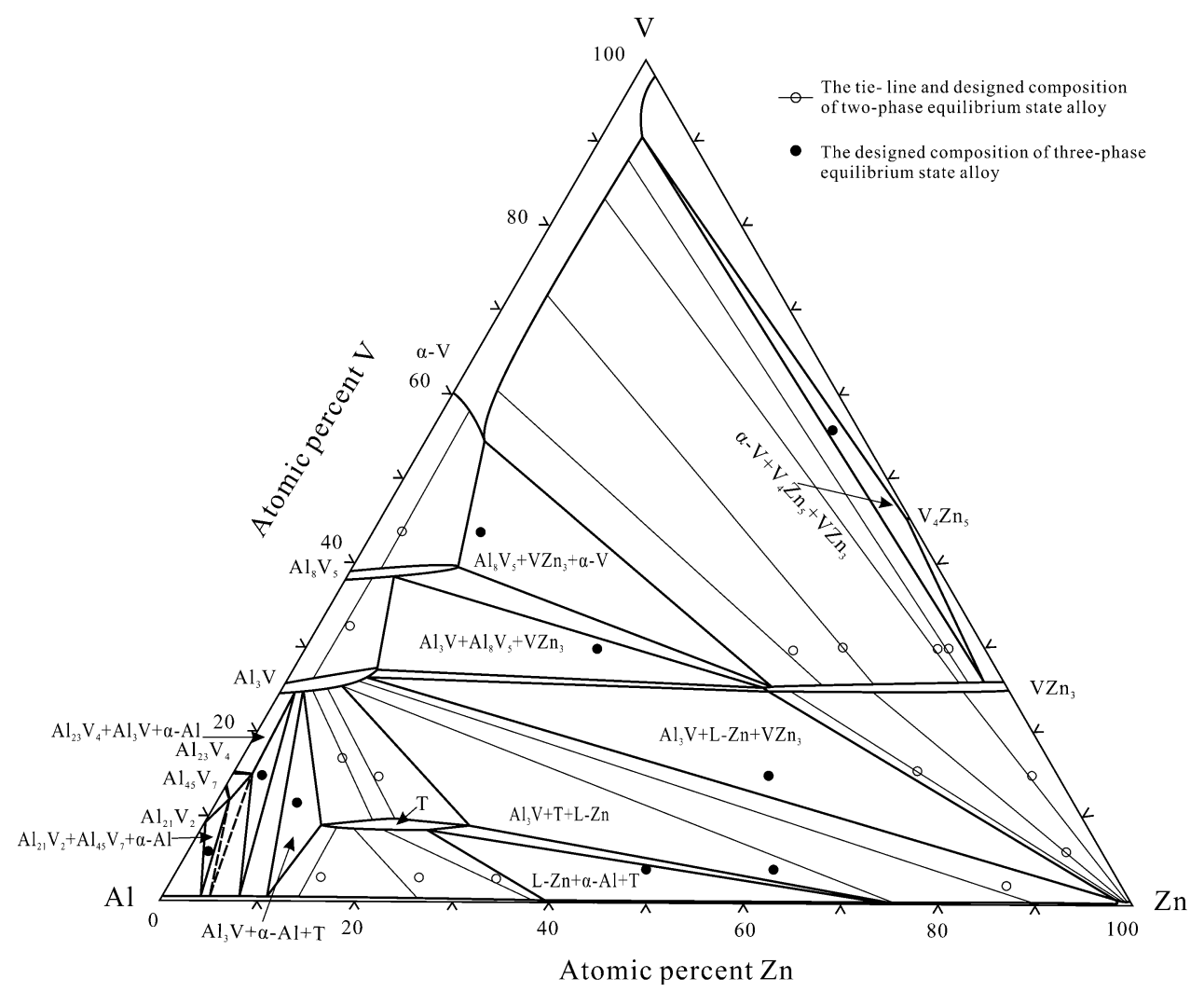

Fig. 10 The $450{ }^{\circ} \mathrm{C}$ isothermal section of Al-V-Zn ternary system

\section{Conclusions}

Based on SEM-EDS analyses and $\mathrm{x}$-ray diffraction results, the $450{ }^{\circ} \mathrm{C}$ isothermal section of the $\mathrm{Zn}-\mathrm{Al}-\mathrm{V}$ ternary system was determined in the present work. The main findings are listed below:

1. A new ternary compound $\mathrm{T}$, containing 8.2-9.9 at.\% $\mathrm{V}, 12.1-27.4$ at.\% $\mathrm{Zn}$, is positively identified in this study. The $\mathrm{T}$ phase only equilibrium with $\mathrm{Al}_{3} \mathrm{~V}, \alpha-\mathrm{Al}$, and L-Zn.

2. Nine three-phase regions have been determined experimentally in the isothermal section at $450{ }^{\circ} \mathrm{C}$, i.e., $\mathrm{L}-\mathrm{Zn}+\mathrm{VZn}_{3}+\mathrm{Al}_{3} \mathrm{~V}, \quad \mathrm{~L}-\mathrm{Zn}+\alpha-\mathrm{Al}+\mathrm{T}, \quad \mathrm{L}-\mathrm{Zn}+$ $\mathrm{Al}_{3} \mathrm{~V}+\mathrm{T}, \boldsymbol{\alpha}-\mathrm{Al}+\mathrm{T}+\mathrm{Al}_{3} \mathrm{~V}, \mathrm{Al}_{21} \mathrm{~V}_{2}+\mathrm{Al}_{45} \mathrm{~V}_{7}+\boldsymbol{\alpha}-\mathrm{Al}$, $\alpha-\mathrm{Al}+\mathrm{Al}_{23} \mathrm{~V}_{4}+\mathrm{Al}_{3} \mathrm{~V}, \mathrm{Al}_{3} \mathrm{~V}+\mathrm{Al}_{8} \mathrm{~V}_{5}+\mathrm{VZn}_{3}, \mathrm{Al}_{8} \mathrm{~V}_{5}+$ $\mathrm{VZn}_{3}+\alpha-\mathrm{V}$, and $\alpha-\mathrm{V}+\mathrm{VZn}_{3}+\mathrm{V}_{4} \mathrm{Zn}_{5}$. The $\left(\mathrm{Al}_{45}\right.$ $\mathrm{V}_{7}+\mathrm{Al}_{23} \mathrm{~V}_{4}+\alpha-\mathrm{Al}$ ) three-phase region can be deduced from the existing results in the present work.

3. The maximum solubility of $\mathrm{Al}$ in $\mathrm{VZn}_{3}$ reaches 25.2 at.\%, but it's only 0.5 at. $\%$ in $\mathrm{V}_{4} \mathrm{Zn}_{5}$; the $\mathrm{Zn}$ solubility in $\alpha-\mathrm{V}, \mathrm{Al}_{8} \mathrm{~V}_{5}, \mathrm{Al}_{3} \mathrm{~V}, \mathrm{Al}_{23} \mathrm{~V}_{4}, \mathrm{Al}_{45} \mathrm{~V}_{7}$, and $\mathrm{Al}_{21} \mathrm{~V}_{2}$ is 5.7, 10.6, 9.2, 1.2, 0.6, and 0.4 at.\%, respectively.

\section{Acknowledgments}

This investigation was supported by National Natural Science Foundation of China (No. 51071135) and Scientific Research Fund of Hunan Provincial Science and Technology Department (No. 2010WK3035).

\section{References}

1. R.W. Sandelin, Galvanizing Characteristics of Different Types of Steel, Wire Wire Prod., 1940, 15, p 655-676

2. J. Foct, P. Perrot, and G. Reumont, Interpretation of the Role of Silicon on the Galvanizing Reaction Based on Kinetics Morphology and Thermodynamics, Scr. Metall. Mater., 1993, 28, p 1195-1200

3. H. Guttman and P. Niessen, Reactivity of Silicon Steels in Hot Dip Galvanizing, Can. Metall. Q., 1972, 11, p 609-615

4. J. Zervoudis and G. Anderson, A Review of Bath Alloy Additives and Their Impact on the Quality of the Galvanized Coating, 6th Asia Pacific General Galvanizing Conference, (Cairns), 2005, p 1-17

5. Syahbuddin, P.R. Munroe, C.S. Laksmi, and B. Gleeson, Effects of 0.1 and 0.2 wt.\% Aluminum Addition to Zinc on the Interdiffusion Between Zinc and Iron at $400{ }^{\circ} \mathrm{C}$, Mater. Sci. Eng. A, 1998, 251, p 87-93

6. T. Kato, K. Nunome, K. Kaneko, and H. Saka, Formation of the Phase at an Interface between an Fe Substrate and a Molten 
0.2 mass\% Al-Zn During Galvannealing, Acta Mater, 2000, 48, p 2257-2262

7. Y. Morimoto, E. McDevitt, and M. Meshii, Characterization of the Fe-Al Inhibition Layer Formed in the Initial Stages of Hotdip Galvannealing, ISIJ Int., 1997, 37, p 906-913

8. E. McDevitt, Y. Morimoto, and M. Meshii, Characterization of Hot-Dip Galvanized the Fe-Al Coating Interfacial Layer in a Commercial Hot-Dip Galvanized Coating, ISIJ Int., 1997, 37, p 776-782

9. X.P. Su, C.J. Wu, D. Liu, F.C. Yin, Z.X. Zhu, and S. Yang, Effect of Vanadium on Galvanizing Si-Containing Steels, Surf. Coat. Technol., 2010, 205(1), p 213-218

10. N.Y. Tang, Determination of Liquid-Phase Boundaries in Zn-Fe-Mx System, J. Phase Equilib. Differ., 1996, 17, p 396

11. J. Nakano, D.V. Malakhov, S. Yamaguchi, and G.R. Purdy, A Full Thermodynamic Optimization of the Zn-Fe-Al System Within the $420-450{ }^{\circ} \mathrm{C}$ Temperature Range, Calphad, 2007, 31(1), p 125

12. C.J. Wu, X.P. Su, D. Liu, F.C. Yin, Z.X. Zhu, and Z. Li, Experimental Investigation of the Zn-Fe-V System at $450{ }^{\circ} \mathrm{C}$, Int. J. Mater. Res., 2010, 12, p 1476-1483

13. T. Maebashi, T. Kozakai, and M. Doi, Phase Equilibria in IronRich Fe-Al-V Ternary Alloy System, Z. Metallkd., 2004, 95, p 11

14. T.B. Massalski, H. Okamoto, P.R. Subramanian, and L. Kacprzak, Binary Alloy Phase Diagrams, 2nd ed., ASM, Materials Park, 1990
15. S.L. Chen and Y.A. Chang, A Thermodynamic Analyses of the Al-Zn System and Phase Diagram Calculation, Calphad, 1993, 17, p 113-124

16. S. An Mey, Reevaluation of the Al-Zn System, Z. Metallkd., 1993, 84, p 451-455

17. K.W. Richter and H. Ipser, Al-V (Aluminum-Vanadium), Z. Metallkd., 2000, 91, p 383

18. W.P. Gong, Y. Du, B.Y. Huang, R. Schmid-Fetzer, C.F. Zhang, and $\mathrm{H}$. $\mathrm{Xu}$, Thermodynamic Reassessment of the Al-V System, Z. Metallkd., 2004, 95, p 978

19. M.G. Chasanov, R. Schablaske, P.D. Hunt, and B. Tani, The Zinc-Vanadium Phase Diagram, Trans. Met. Soc. AIME, 1963, 227, p 485

20. W. Piotrowski, The Structure of Zinc Alloys with Vanadium, Hutnik, 1995, 32, p 135

21. J.F. Smith, The V-Zn (Vanadium-Zinc) System, J. Alloy Phase Diagr., 1989, 5, p 136

22. C.J. Wu, X.P. Su, D. Liu, X.M. Wang, J.H. Wang, Z. Li, and H.P. Peng, The V-Zn Binary System: New Experimental Results and Thermodynamic, Calphad, 2011, 35, p 403-410

23. X. Su, N.-Y. Tang, and J.M. Toguri, $450{ }^{\circ} \mathrm{C}$ Isothermal Section of the Fe-Zn-Si Ternary Phase Diagram, Can. Metall. Q., 2001, 40, p 377

24. J.L. Murray, Al-V (Aluminum-Vanadium), Bull. Alloy Phase Diagr., 1989, 10, p 351 